ISSN 1392-3196 / e-ISSN 2335-8947

Zemdirbyste-Agriculture, vol. 103, No. 3 (2016), p. 305-310

DOI 10.13080/z-a.2016.103.039

\title{
Effect of the inoculant on the fermentation, microbial population and aerobic stability of whole plant maize ensiled in large tubes
}

\author{
Jonas JATKAUSKAS, Vilma VROTNIAKIENE \\ Institute of Animal Science, Lithuanian University of Health Sciences \\ R. Žebenkos 12, Baisogala, Radviliš̌kis distr., Lithuania \\ E-mail: lgipts@gmail.com
}

\begin{abstract}
This study evaluated the efficacy of the use of inoculant containing Lactobaillus buchnery in combination with homofermentative lactic acid bacteria strains Lactobacillus plantarum and Entrococcus faecium in improving characteristics of maize silage stored in a large tube. Maize plants were harvested at the dough stage of maturity, containing $339.6 \mathrm{~g} \mathrm{~kg}^{-1}$ dry matter (DM), chopped and ensiled in large tubes (1700-1800 kg each) after application of tap water (control) or inoculant suspension (inoculated) containing $1 \times 10^{8} \mathrm{cfu} \mathrm{ml}^{-1}$ of Lactobacillus plantarum, Entrococcus faecium and Lactobacillus buchneri (20:30:50). The final application rate of fresh forage was $1.0 \times 10^{5}$ $\mathrm{cfu} \mathrm{g}^{-1}$ forage. The silos were stored for 156 days at outdoor temperature under farm conditions. After that the silos were opened and sampled, the chemical composition, the count of yeasts and moulds and aerobic stability were determined. Visible signs of mould growth on the surface of large tubes were assessed on day 0, 7, 14, 21, 28 and 35 after removing plastic cover from large tubes and scored using a scale from 0 to 5 . The acetic acid concentration was higher in inoculated silages versus the control (20.3 vs $\left.17.1 \mathrm{~g} \mathrm{~kg}^{-1} \mathrm{DM}\right)$. The inoculated silages had a lower $\mathrm{pH}$ value and butyric acid concentration than the control, and a higher lactic-to-acetic acid ratio (1.95 vs 1.80). The inoculant treatment reduced DM losses $\left(87 v s 74 \mathrm{~g} \mathrm{~kg}^{-1} \mathrm{DM}\right)$. The counts of yeasts and moulds were lower in the inoculated silages when compared with the control silages, confirming the ability of this inoculum to enhance aerobic stability of maize silages in large tube silos. The surface area covered with moulds in the control large tubes was 4-5 times greater than that in the inoculated large tubes. Under laboratory conditions the aerobic deterioration of the inoculant treated silages was delayed by 72 hours $(3$ days $)(P<0.05)$ compared with the untreated silage. Treatment with inoculant significantly increased aerobic stability of large tube maize silages.
\end{abstract}

Key words: aerobic stability, inoculant, maize, molds, silage.

\section{Introduction}

The aims of feed preservation are to inhibit the growth of undesirable micro-organisms, to prevent the spoilage of the feedstuffs and to minimize nutrient and energy losses. Grass or maize silages exposed to air deteriorate due microbial activity which could reduce silage quality (Weinberg et al., 2009; Gerlach et al., 2013). Aerobic deterioration, caused by the activities of bacteria, yeasts and moulds is a significant problem affecting feed quality, with changing the chemical composition of the silages and with resulting loss of dry matter and nutritional components (Tabacco et al., 2011). On many farms, silage is often subject to varying degrees of aerobic deterioration before and during feeding. For example, the inability to remove sufficient quantities of silage from silos between feedings can result in prolonged exposure to air. Feeds that have undergone aerobic deterioration have reduced nutritional value and present hazards to the animals and environment. In order to better the fermentation and to achieve other collateral effects, such as longer aerobic stability, many farmers are currently using silage inoculants (Muck, 2012). Microbial additives containing lactic acid bacteria (LAB) are commonly used for silage preservation to achieve a rapid $\mathrm{pH}$ drop through organic acid production, and to improve aerobic stability, by inhibiting spoilage moulds and yeasts (Tabacco et al., 2011). The homofermentative lactic acid bacteria (Lactobacillus plantarum, Entrococcus faecium, Pediococcus acidilactici, L. lactis) rapidly produce lactic acid which helps to preserve forage mass, however, might decrease aerobic stability of silage. A heterofermentative LAB (L. buchneri, L. brevis) has been shown to convert lactic to acetic acid with good antifungal properties and thus improve the stability of silages when they are exposed to air (Oude Elferink et al., 2001; Muck, 2012). However, treating silages with heterolactic LAB has led to higher dry matter losses compared to control silages or silages treated with homolactic LAB (Driehuis et al., 2001). Combining heterofermentative LAB with homofermentative $\mathrm{LAB}$ allows gaining positive attributes when active silages ferment and when silages are exposed to air, respectively. Filya (2003) combined L. buchnery with $L$. plantarum and found that the dry matter losses of maize silage were less for the combination of two strains than with L. buchnery alone. Inoculants showed their 
efficacy in laboratory-scale studies; however, the effect of inoculation under field conditions was less than expected from laboratory-scale studies (Kleinschmit, Kung, 2006; Mari et al., 2009; Jatkauskas, Vrotniakiene, 2013). Moreover, research on the ensiling of whole-crop maize with inoculants and the effects of inoculants may vary from one place to another (Schmidt, Kung, 2010). The objective was to evaluate the effectiveness of combining Lactobacillus buchneri CCM 1819/ DSM 22501 with $L$. plantarum DSM16568 and Entrococcus faecium NCIMB 11181/ DSM 22502 for the fermentation parameters, microbial composition and aerobic stability of whole crop maize silage stored in farm large tube silos.

\section{Material and methods}

Ensiling procedure and treatments. Research was carried out in the experimental farm of Institute of Animal Science of Lithuanian University of Health Sciences from September 2013 to April 2014. Whole crop maize (Zea mays L.), cultivar 'Baxxos FAO 200', was harvested and chopped at the dough stage of maturity of grain, $339.6 \mathrm{~g} \mathrm{~kg}^{-1}$ dry matter (DM) of whole plant. Maize was harvested with a forage harvester "Jaguar 840" (CLAAS, Germany) adjusted to achieve a $10 \mathrm{~mm}$ theoretical chop length. Immediately after harvesting, the chopped forage was carted from the field to the ensiling and storage area and was ensiled into a hermetic plastic large tube, using Murska tube bagging equipment with a loading tunnel can and additive applicator. The following treatments were applied to fresh forage: untreated (control) no additive and inoculated with Lactobacillus buchneri CCM 1819/ DSM 22501 combined with Lactobacillus plantarum DSM16568 and Entrococcus faecium NCIMB 11181/ DSM 22502. Inoculant was supplied by Chr. Hansen (Denmark). The stated total number of bacteria in the product was $1.3 \times 10^{11}$ colony forming units $\mathrm{g}^{-1}\left(\mathrm{cfu} \mathrm{g}^{-1}\right)$. The inoculant was applied at a rate of $4 \mathrm{~L}_{\text {suspension over }}$ a ton of freshly chopped maize (inoculant was dissolved in $4 \mathrm{~L}$ tap water $4 \mathrm{~h}$ before application in accordance with the manufacturer's instructions) in order to obtain $1.0 \times$ $10^{5} \mathrm{cfu} \mathrm{g}^{-1}$ forage. The suspension was plated on de Man, Rogosa and Sharpe agar and counted for LAB number following the ISO method 15214 Microbiology of food and animal feeding stuffs - Horizontal method for the enumeration of mesophilic lactic acid bacteria - Colonycount technique at $30^{\circ} \mathrm{C}$. To compensate for the water that was added to the treated silage, the control treatment was sprayed with $4 \mathrm{~L}$ of tap water over a ton of fresh material to keep it at the same level of moisture as the treated silages. Ten hermetic plastic large tube silages (1700-1800 kg each) for each treatment were prepared. During large tube filling, one control bag (made from four layers cheesecloth) filled with $1 \mathrm{~kg}$ ensiling mass was inserted into each large tube for determining DM losses. DM loss was estimated by measuring differences in the control bag weight and DM content at ensiling and after 156 days of storage. The silages were stored outdoors under farm conditions.

Sample collection, chemical and microbial composition analyses. Five representative samples of the chopped whole crop maize were collected at the time of ensiling for subsequent analysis. On day 156 of storage the large tube silages were core sampled for chemical and microbial analysis. Five representative silage samples were collected from each large tube. At the end of ensiling period, 156 days, silages were subjected to an aerobic stability test at the laboratory and field conditions. The untreated chopped whole crop maize at ensiling and the silages were analyzed for the DM content, nutrient composition and also the silages were analysed for the volatile fatty acids (acetic, butyric and propionic acid), lactic acid, ammonia-N and alcohols concentration as described previously by Jatkauskas et al. (2013). The microbial composition of the fresh forage and silages was described according to the number of yeast, mould, lactobacilli and clostridia spores in five samples. In addition to this, silages were sampled and yeast and mould counts were measured on day $8,14,21,28$ and 35 after removing plastic cover of the large tubes. Microbial variables were measured at National Food and Veterinary Risk Assessment Institute. Lactobacilli, clostridia, and yeast and mould counts were determined by the spread plate method using ISO 15214:1998, ISO 7937:2004 Microbiology of food and animal feeding stuffs Horizontal method for the enumeration of Clostridium perfringens - Colony-count technique and ISO 215271:2008 Microbiology of food and animal feeding stuffs - Horizontal method for the enumeration of yeasts and moulds. Part 1: Colony count technique in products with water activity greater than 0.95 procedures, respectively. Aerobic stability measurement. The aerobic stability of the silage was determined on the field and laboratory scale. For aerobic stability test on the field scale, in large tubes, after removing plastic cover, temperature data loggers (EBRO EBI 20) were placed in 5 control large tubes and in 5 inoculated large tubes (1 data logger per 1 large tube) to monitor temperature change inside the silage automatically every 6 hours for up to 35 day exposure to air period (from day 156 to day 191 of storage). One data logger measured air (ambient) temperature close to the silos. During the field scale aerobic stability test visible signs of mould growth on the surface of the large tubes were assessed on day $0,8,14$, 21,28 and 35 after removing the plastic cover from the large tubes and scored using a scale from 0 to 5 .

For aerobic stability test on the laboratory scale, a $1000 \pm 10 \mathrm{~g}$ sample from each silo (5 large tubes from each treatment) was loosely placed into a polystyrene box according to the recommendations from Deutsche Landwirtschafts-Gesellhaft e.V./ internationally acknowledged German Agricultural Society Guidelines and allowed to aerobically deteriorate at constant room temperature $\left(\sim 20^{\circ} \mathrm{C}\right)$. The top and bottom of the boxes contained a 2-cm-diameter hole to allow air to enter and $\mathrm{CO}_{2}$ to leave. A transducer was placed in the centre of the silage mass through a hole in the cover of the box, which exposed the silage to air. These silages were not disturbed during the period of recording the temperatures. The ambient temperature and the temperature of each silage were recorded every 6 hours by a data logger. The ambient room temperature was measured by using an empty control box. The aerobic stability of silages was examined by calculating the differences between the silage temperature and ambient room temperature adjusted for the base ambient temperature. The aerobic stability of the silages was denoted by the time that elapsed before a $3^{\circ} \mathrm{C}$ in silage temperature above ambient temperature.

Statistical analysis. After analyzing data for normal distribution the silage composition data were analyzed using Proc GLM of SAS (2002), version 8.02 
and the statistical model used was a randomized complete block. The data of aerobic stability of the silages were estimated in the following two ways: a) hours for a $3^{\circ} \mathrm{C}$ increase in temperature (laboratory test) and b) statistical analysis using a model as randomized complete block and temperature measurements data treated as repeated measurements (sets of data for every 6 hours - field test). T-test (LSD) was used to indicate significant differences between untreated and additive treatment. Significance was declared at $P<0.05$.

\section{Results and discussion}

The chemical composition, fermentation characteristics and microbiological composition of fresh maize and silages. The mean chemical and microbiological composition of whole crop maize at ensiling is summarised in Table 1. Dry matter concentration of the fresh whole plant maize at harvesting reached the value of $339.6 \mathrm{~g} \mathrm{~kg}^{-1}$ forage, soluble carbohydrates concentration was medium (88.3 $\mathrm{g} \mathrm{kg}^{-1} \mathrm{DM}$ ) and crude protein content was low (98.7 $\left.\mathrm{g} \mathrm{kg}^{-1} \mathrm{DM}\right)$. The buffer capacity was typical of whole plant maize $\left(20.6 \mathrm{mEq} 100 \mathrm{~g} \mathrm{D}^{-1}\right)$. Consequently, forage was characterized as moderately difficult to easy to ensile. The numbers of initial moulds and yeasts in the fresh whole crop maize were high, each being $>3.5 \log _{10}$ $\mathrm{cfu}^{-1}$. Clostridial spore number was low.

Nutrient content, dry matter losses, fermentative profiles and microbial populations of large tube maize silages are shown in Table 1. Inoculation had a small effect on dry matter concentration, but dry matter corrected for volatiles content was higher $(P<0.05)$ in the inoculated silages compared with the control. DM loss was lower by $13 \mathrm{~g} \mathrm{~kg}^{-1} \mathrm{DM}(P<0.05)$ and the concentration of crude protein was higher by $6.4 \mathrm{~g} \mathrm{~kg}^{-1} \mathrm{DM}(P<0.05)$ in inoculant treated silages than in control silages, suggesting that plant nutrients were less extensively affected in inoculant treated silage. Lower DM losses in silage are desirable because they reflect more efficient fermentation in the silages and indicate greater availability of nutrients for animals (Filya et al., 2006). Inoculant treatment accelerated fermentation, as indentified by the lower $(P<0.05) \mathrm{pH}$ drop at day 2 after ensiling compared with the untreated control. The $\mathrm{pH}$ at day 156 of storage of inoculant treated silages was lower $(P<0.05)$ than the control. Such shift (lower $\mathrm{pH})$ in silage with the inoculants is consistent with summaries of studies where inoculants were successful in reducing $\mathrm{pH}$ value (Hu et al., 2009). Concentration of acetic acid was higher $(P<0.05)$ and lactic-to-acetic acid ratios was lower (1.8) in inoculant treated silages when compared with the control (1.9). The results in the current study suggest that the fermentation in the inoculated silage was dominated by heterolactic L. buchnery bacteria, which is in agreement with past findings (Arriola et al., 2011). Inoculation of L. buchneri to corn forage usually increases the concentration of acetate and reduces the lactate concentration (Hu et al., 2009). The concentrations of butyrate were negligible in control and inoculated silages; however, inoculation significantly decreased $(P<0.05)$ butyric acid formation. Propionic acid, alcohols and ammonia-N were unaffected by inoculation, as concentrations did not differ between treatments.

The microbial populations in the samples of cored silages are shown in Table 1. Inoculant increased lactobacilli and decreased yeast and mould numbers of whole crop maize silages compared with the control silage, and this is in agreement with the results reported by $\mathrm{Hu}$ et al. (2009) and Tabacco et al. (2011). As expected, greater counts of lactobacilli were detected in the inoculated silage versus those without this inoculant (6.42 $\log _{10}$ cfu g-1 vs $5.05 \log _{10}$ cfu g ${ }^{-1}$ of fresh silage; $P<0.05)$. This finding suggested that inoculation dominated the fermentation. Schmidt et al. (2008) and Mari et al. (2009) also reported greater numbers of lactic acid bacteria in inoculated corn silages than in untreated corn silage and further confirmed that treated silages had markedly greater numbers of $L$. buchneri. The numbers of yeasts and moulds were lower in inoculated silages when compared with the control silage (2.15 vs 2.35 $\log _{10}$ cfu g $^{-1}$ and 1.15 vs $1.21 \log _{10}$ cfu g $^{-1}$ fresh forage, respectively; $P<0.05)$. These findings are in agreement with reports of Fylia et al. (2006) and Muck (2012),

Table 1. The chemical composition, fermentation characteristics and microbiological composition of fresh maize and silages $(\mathrm{n}=5)$

\begin{tabular}{|c|c|c|c|c|c|c|}
\hline \multirow[b]{2}{*}{ Variable } & \multicolumn{3}{|c|}{ Fresh maize } & \multicolumn{3}{|c|}{ Silages } \\
\hline & $\mathrm{n}$ & mean & $\begin{array}{l}\text { standard } \\
\text { deviation }\end{array}$ & control & inoculated & mean \\
\hline Dry matter $\mathrm{g} \mathrm{kg}^{-1}$ & 5 & 339.6 & 7.682 & 320 & 323 & 321 \\
\hline Dry matter corrected for volatiles $\mathrm{g} \mathrm{kg}^{-1}$ & 5 & & 4.906 & 329 & $334 *$ & 331 \\
\hline Crude protein, $\mathrm{g} \mathrm{kg}^{-1} \mathrm{DM}$ & 5 & 98.7 & 4.906 & 81.3 & $87.7 *$ & 84.5 \\
\hline Water soluble carbohydrates $\mathrm{g} \mathrm{kg}^{-1} \mathrm{DM}$ & 5 & 88.3 & 1.983 & 8.3 & 8.2 & 8.3 \\
\hline Acid detergent fibre $\mathrm{g} \mathrm{kg}^{-1} \mathrm{DM}$ & 5 & 249.5 & 17.035 & 226 & 221 & 223 \\
\hline Neutral detergent fibre $\mathrm{g} \mathrm{kg}^{-1} \mathrm{DM}$ & 5 & 442.0 & 25.858 & 381 & 379 & 380 \\
\hline Buffer capacity mEq $100 \mathrm{~g} \mathrm{DM}^{-1}$ & 5 & 20.6 & 2.603 & & & \\
\hline Lactic acid bacteria $\log _{10} \mathrm{cfu} \mathrm{g}^{-1}$ & 5 & 6.08 & 0.502 & 5.05 & 6.42 & 5.74 \\
\hline Clostridia $\log _{10} \mathrm{cfu} \mathrm{g}^{-1}$ & 5 & $<1$ & 0 & $<1$ & $<1$ & $<1$ \\
\hline Yeast $\log _{10} \mathrm{cfu} \mathrm{g}^{-1}$ & 5 & 5.23 & 0.973 & 2.35 & $2.15^{*}$ & \\
\hline Moulds $\log _{10}$ cfu g $^{-1}$ & 5 & 3.83 & 0.462 & 1.21 & $1.15^{*}$ & \\
\hline $\mathrm{pH}$ day 0 & 5 & 5.40 & 0.059 & 5.40 & 5.40 & 5.40 \\
\hline pH day 2 & 5 & & & 4.00 & $3.65^{*}$ & 3.83 \\
\hline pH day 156 & 5 & & & 3.73 & $3.60 *$ & 3.67 \\
\hline Lactic acid $\mathrm{g} \mathrm{kg}^{-1} \mathrm{DM}$ & 5 & & & 33.4 & 36.5 & 35.0 \\
\hline Acetic acid $\mathrm{g} \mathrm{kg}^{-1} \mathrm{DM}$ & 5 & & & 17.1 & $20.3 *$ & 18.7 \\
\hline Butyric acid $\mathrm{g} \mathrm{kg}^{-1} \mathrm{DM}$ & 5 & & & 0.50 & $0.30 *$ & 0.40 \\
\hline Propionic acid $\mathrm{g} \mathrm{kg}^{-1} \mathrm{DM}$ & 5 & & & 0.10 & 0.10 & 0.10 \\
\hline Alcohols $\mathrm{g} \mathrm{kg}^{-1} \mathrm{DM}$ & 5 & & & 5.80 & 5.30 & 5.50 \\
\hline Amoniacial-N, $\mathrm{g} \mathrm{kg}^{-1} \mathrm{~N}$ & 5 & & & 32.7 & 31.0 & 31.9 \\
\hline Dry matter loss $\mathrm{g} \mathrm{kg}^{-1} \mathrm{DM}$ & & & & 87.3 & $74.1 *$ & 81.2 \\
\hline
\end{tabular}

$\mathrm{DM}$ - dry matter, cfu - colony forming units; * - statistically significant difference $v s$ control $P<0.05$ 
and the improvement in aerobic stability appears to be mainly due to the reduction in yeast population during the anaerobic phase of silage conservation.

Aerobic stability of large tube whole crop maize silages during exposure to air for 35 days under laboratory and field conditions. The results in the current study indicate clearly that inoculation with Lactobacillus buchneri in combination with a homofermentative LAB improved aerobic stability. During aerobic exposure in laboratory the untreated silage had a temperature rise of more than $3{ }^{\circ} \mathrm{C}$ above the ambient after 102 hours, when the inoculant treated silage had a temperature rise of more than $3^{\circ} \mathrm{C}$ above the ambient after 174 hours. The difference was statistically significant $(P<0.05)$ (Fig. 1$)$. The aerobic deterioration of the inoculant treated silages was delayed by 72 hours $(3$ days $)(P<0.05)$ compared with the control silage. The temperature changes data of silages indicated that significant difference at $P<0.05$ between untreated and inoculants treated silages begin at 84 hours after opening of the silo and this significant difference continues up to 210 hours after opening silages when transferred to the laboratory. In this experiment, the inoculated maize silages had a fermentation profile with a higher level of acetic acid than that of the control silages, and this was reflected in better aerobic stability, due to the inhibition of yeasts and moulds growth during air exposure, as highlighted by Tabacco et al. (2009) and Filya (2003). These fermentation characteristics and aerobic stability improvement are common when L. buchneri is used as a silage inoculant and are consistent with those observed by Filya et al. (2006) and Hu et al. (2009).

The exposure of silage to air during the feedout phase can initiate the aerobic spoilage process of the mass and the activity of yeasts, which metabolize soluble carbohydrates and fermentation end products into carbon dioxide and water, increase temperature and $\mathrm{pH}$, cause DM losses and decrease nutritive value of feed (Chen, Weinberg, 2009). To estimate the effect of inoculation on silages aerobic stability and yeast and mould growth in farm conditions, the large tube silages after removing plastic cover were left to deteriorate (for aerobic exposure) in the field for up to 35 days. The results of the temperature change during 35 days aerobic exposure inside undisturbed whole crop maize large tubes after removing plastic cover are shown in Figure 2. The temperature in the inoculant treated silage was almost constant during the 35-day exposure at temperatures just above $0^{\circ} \mathrm{C}$ (temperature close to ambient) with minor increase after 17 days. The untreated silage started to heat after 84 hours and had a rapid temperature increase, and within 180 and 324 hours reached $20^{\circ} \mathrm{C}$ and $40^{\circ} \mathrm{C}$, respectively. This agrees with our previous laboratory experiment (Jatkauskas, Vrotniakiene, 2013) with grass and whole crop maize silages. Rabelo et al. (2015) concluded that the association between L. buchnery and L. plantarum seems to be more appropriate to improve the fermentation and aerobic stability of whole-crop corn silages.

Yeasts and moulds development in large tubes. The dynamics of yeasts and moulds development in large tube whole crop maize silages are given in Table 2. It was detected that inoculant treated silages were significantly less contaminated with yeasts $\left(2.35 \log 10 \mathrm{cfu} \mathrm{g}^{-1}\right.$ vs 2.15 $\left.\log 10 \mathrm{cfu} \mathrm{g}^{-1}\right)$ and moulds $\left(1.21 \log _{10} \mathrm{cfu} \mathrm{g}^{-1}\right.$ vs $1.15 \log _{10}$ cfu $^{-1}$ ). During exposure (at day 8, 14, 21, 28 and 35 after removing of plastic cover) yeast and mould increased in both the inoculated and untreated silages. However, the number of yeasts and moulds increased more rapidly in the control silages than in the inoculated ones. The highest differences of yeast and mould counts between the control and inoculated silages were found at day 28 of aerobic exposure (5.99 vs $4.72 \log _{10} \mathrm{cfu} \mathrm{g}^{-1}$ for the yeasts and 6.95 vs $3.99 \log _{10} \mathrm{cfu} \mathrm{g}^{-1}$ for the moulds), which indicated that yeasts and moulds were effectively inhibited by the inoculant. Mari et al. (2009) have reported that the numbers of yeasts were lower in the silage treated with an inoculant versus the silage without this inoculant. Ström et al. (2002) showed the ability of a L. plantarum strain to inhibit or change the morphology of selected fungi, due

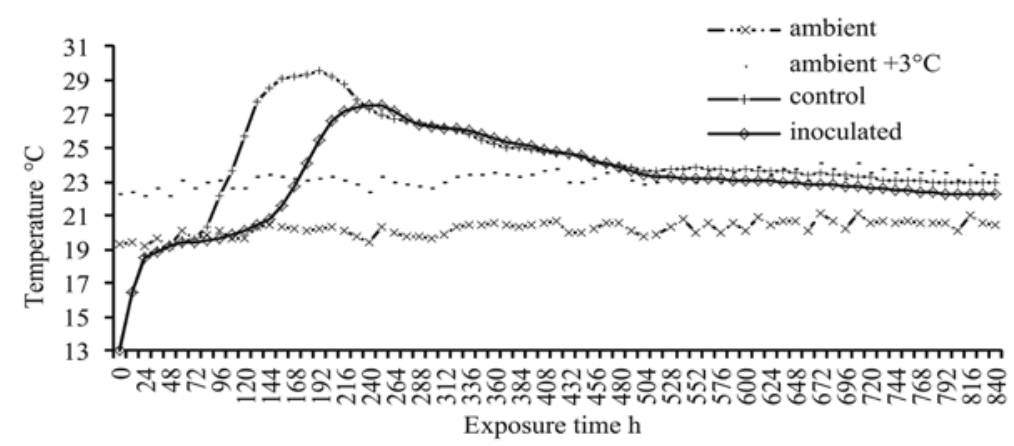

Figure 1. Temperature changes in the control and inoculated whole crop maize silages during exposure to air under laboratory conditions

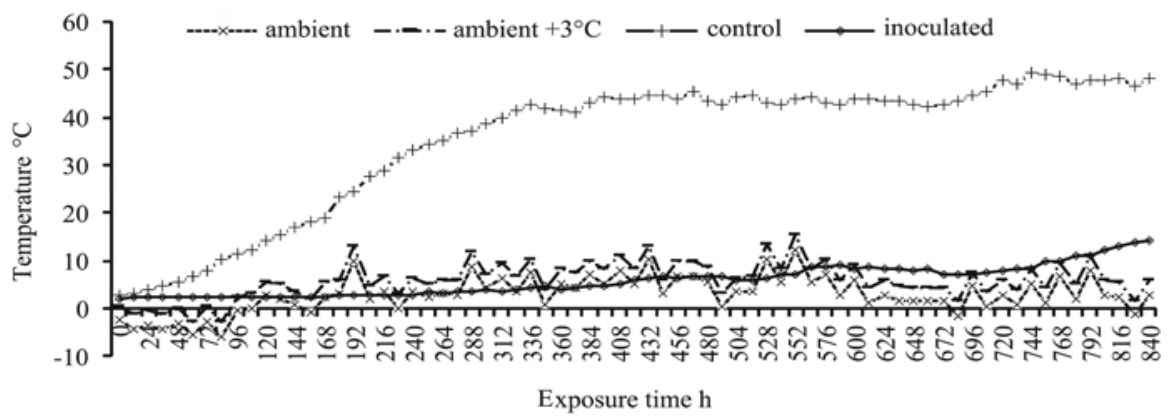

Figure 2. Temperature changes in the control and inoculated whole crop maize silages during exposure to air under field conditions 
Table 2. Yeasts and moulds development in whole crop maize large tube silages during 35 days' exposure to air under field conditions

\begin{tabular}{|c|c|c|c|}
\hline Treatment & Control & Inoculated & Average \\
\hline \multicolumn{4}{|c|}{ At time of removal of the plastic film } \\
\hline Yeast count $\log _{10} \mathrm{cfu} \mathrm{g}^{-1}$ & 2.35 & $2.15^{*}$ & 2.25 \\
\hline Moulds count $\log _{10}$ cfu g $^{-1}$ & 1.21 & $1.15^{*}$ & 1.17 \\
\hline Visible yeast score & 0 & 0 & 0 \\
\hline Visible mould score & 0.3 & 0 & 0.15 \\
\hline \multicolumn{4}{|c|}{ Day 8 after removing plastic film } \\
\hline Yeast count $\log _{10} \mathrm{cfu} \mathrm{g}^{-1}$ & 3.20 & $2.79 *$ & 3.00 \\
\hline Moulds count $\log _{10} \mathrm{cfu} \mathrm{g}^{-1}$ & 2.40 & $2.02 *$ & 2.21 \\
\hline Visible yeast score & 0.10 & 0 & 0.05 \\
\hline Visible mould score & 1.00 & $0.30 *$ & 0.65 \\
\hline \multicolumn{4}{|c|}{ Day 14 after removing plastic film } \\
\hline Yeast count $\log _{10}$ cfu g $^{-1}$ & 3.97 & $3.50^{*}$ & 3.74 \\
\hline Moulds count $\log _{10} \mathrm{cfu} \mathrm{g}^{-1}$ & 3.39 & $2.83 *$ & 3.11 \\
\hline Visible yeast score & 0.50 & 0.10 & 0.30 \\
\hline Visible mould score & 1.50 & $0.60 *$ & 1.05 \\
\hline \multicolumn{4}{|c|}{ Day 21 day after removing plastic film } \\
\hline Yeast count $\log _{10} \mathrm{cfu} \mathrm{g}^{-1}$ & 5.62 & $4.82 *$ & 5.22 \\
\hline Moulds count $\log _{10}$ cfu g $^{-1}$ & 5.55 & $3.78 *$ & 4.67 \\
\hline Visible yeast score & 1.00 & $0.20 *$ & 0.60 \\
\hline Visible mould score & 2.90 & $0.80^{*}$ & 1.85 \\
\hline \multicolumn{4}{|c|}{ Day 28 after removing plastic film } \\
\hline Yeast count $\log _{10} \mathrm{cfu} \mathrm{g}^{-1}$ & 5.99 & $4.72 *$ & 5.35 \\
\hline Moulds count $\log _{10} \mathrm{cfu} \mathrm{g}^{-1}$ & 6.95 & $3.99 *$ & 5.47 \\
\hline Visible yeast score & 2.20 & $0.50 *$ & 1.35 \\
\hline Visible mould score & 4.30 & $1.10^{*}$ & 2.70 \\
\hline \multicolumn{4}{|c|}{ Day 35 after removing plastic film } \\
\hline Yeast count $\log _{10} \mathrm{cfu} \mathrm{g}^{-1}$ & 5.61 & 5.57 & 5.59 \\
\hline Moulds count $\log _{10} \mathrm{cfu} \mathrm{g}^{-1}$ & 5.32 & 4.57 & 4.90 \\
\hline Visible yeast score & 4.3 & $0.6^{*}$ & 2.45 \\
\hline Visible mould score & 5.0 & $1.6^{*}$ & 3.30 \\
\hline $\begin{array}{l}\text { Quantities of suitable for } \\
\text { feeding silage after } 35 \text { days } \\
\text { exposure to air } \%\end{array}$ & 9.2 & $72.9^{*}$ & 41.0 \\
\hline
\end{tabular}

* - statistically significant difference $v s$ control $P<0.05$

to antifungal cyclic dipeptides. The author points out that the antifungal inhibition of L. buchneri is largely related to the acetate production, but other antifungal compounds could also be produced by this strain.

Visual moulds score at opening large tubes (day 0 ) and during 35 days' aerobic exposure (day 8, 14, 21, 28 and 35) are shown in Table 2. Inoculation decreased the growth of fungi on the surface of the inoculated large tubes. The surface area covered with moulds in the control large tubes was 4-5 times greater than that in the inoculated large tubes. Inoculation with $L$. buchneri 40788 resulted in silage with a higher concentration of acetic acid and lower numbers of yeasts. Reduction in yeast and mould population during anaerobic phase of silage conservation and during aerobic exposure appears to be the main reason for the improvement of aerobic stability of the inoculated silages (Reich, Kung, 2010).

The quantities of feedable silage in the inoculated large tubes after 35 days' aerobic exposure were greater than those of the untreated silage $(72.9 \%$ vs $9.2 \%)$. These finding are in agreement with the results presented in other studies in which L. buchnery was used alone or in combination with homolactic bacteria. The positive effect of the inoculation on the fermentation parameters, aerobic stability and the quantity of edible silage by cows was pointed out in the study of Ferris et al. (2015). Inoculation with $L$. buchneri combined with $L$. plantarum and L. buchneri combined with $P$. acidilactici resulted in an improvement in feedable DM and a NDF-D when compared to untreated silage (Reich, Kung, 2010).

\section{Conclusions}

1. Inoculation with Lactobacillus buchnery in combination with L. plantarum and Entrococcus faecium resulted in silage with a higher concentration of acetic acid, lower dry matter losses, lower concentration of butyric, lower numbers of yeast and moulds and fewer visible signs of moulds.

2. The data from this study show the effectiveness of the used inoculant in increasing aerobic stability of whole crop maize large tube silage and positive effect on the quantities of suitable for feeding silage upon exposure to air.

Received 23022016 Accepted 24052016

\section{References}

Arriola K. G., Kim S. C., Adesogan A. T. 2011. Effect of applying inoculants with heterolactic or homolactic and heterolactic bacteria on the fermentation and quality of corn silage. Journal of Dairy Science. 94 (3): 1511-1516 http://dx.doi.org/10.3168/jds.2010-3807

Chen Y., Weinberg Z. G. 2009. Changes during aerobic exposure of wheat silages. Animal Feed Science and Technology, 154 (1-2): 76-82 http://dx.doi.org/10.1016/j.anifeedsci.2009.08.004

Driehuis F., Oude Elferink S. J. W. H., Van Wikselaar P. G. 2001. Fermentation characteristics and aerobic stability of grass silage inoculated with Lactobacillus buchneri, with or without homofermentative lactic acid bacteria. Grass and Forage Science. 56 (4): 330-343 http://dx.doi.org/10.1046/j.1365-2494.2001.00282.x

Ferris C., Demey V., Chevaux E. 2015. The effect of treating whole crop wheat with a bacterial inoculants on aerobic stability on farm scale silo. $17^{\text {th }}$ International Silage Conference. Piracicaba, Sao Paulo, Brazil, p. 356

Filya I. 2003. The effect of Lactobacillus buchnery and Lactobacillus plantarum on the fermentation, aerobic stability, and ruminal degradability of low dry matter corn and sorghum silages. Journal of Dairy Science, 86(11): 3575-3581 http://dx.doi.org/10.3168/jds.S0022-0302(03)73963-0

Filya I., Sucu E., Karabult A. 2006. The effect of Lactobacillus buchneri on the fermentation, aerobic stability and ruminal degradability of maize silage. Journal of Applied Microbiology. 101 (6): 1216-1223 $\mathrm{http}: / / \mathrm{dx}$.doi.org/10.1111/j.1365-2672.2006.03038.x

Gerlach K., Rob F., Weib K., Buscher V., Sudekum K. 2013. Changes in maize silage fermentation products during aerobic deterioration and effects on dry matter intake by goats. Agricultural and Food Science, 22 (1): 168-181

$\mathrm{Hu}$ W., Schmidt R. J., McDonell E. E., Klingerman C. M., Kung Jr. L. 2009. The effect of Lactobacillus buchneri 40788 or Lactobacillus plantarum MTD-1 on the fermentation and aerobic stabilityof corn silages ensiled at two dry matter contents. Journal of Dairy Science. 92(8):3907-3914 http://dx.doi.org/10.3168/jds.2008-1788

Jatkauskas J., Vrotniakiene V. 2013. Evaluation of fermentation parameters, microbiological composition and aerobic stability of grass and whole crop maize silages treated with microbial inoculants. Zemdirbvste-Agriculture. 100 (2): 143-150 http://dx.doi.org/10.13080/z-a.2013.100.018

Jatkauskas J., Vrotniakiene V., Ohlsson Ch., Lund B. 2013. The effects of three silage inoculants on aerobic stability in grass, clover-grass, lucerne and maize silages. Agricultural and Food Science, 22 (1): 137-144

Kleinschmit D. H., Kung Jr. L. 2006. A meta-analysis of the effcts of Lactobacillus buchneri on fermentation and aerobic stability of corn and grass and small-grain silages. Journal of Dairy Science. 89 (10): 4005-4013 http://dx.doi.org/10.3168/jds.S0022-0302(06)72444-4

Mari L. J., Schmidt R. J., Nussio L. G., Hallada C. M., Kung Jr. L. 2009. Short communication: An evaluation of the effectiveness of Lactobacillus buchneri 40788 to alter 
fermentation and improve the aerobic stability of corn silage in farm silos. Journal of Dairy Science, 92 (3): 1174-1176 http://dx.doi.org/10.3168/jds.2008-1700

Muck R. 2012. Microbiology of ensiling. $16^{\text {th }}$ International Silage Conference. Hameenlinna, Finland, p. 75

Oude Elferink S. J. W. H., Krooneman J., Gottschal J. C. Spoelstra S. F., Faber F., Driehuis F. 2001. Anaerobic conversion of lactic acid to acetic acid and 1,2-propanediol by Lactobacillus buchneri. Applied and Environmental Microbiology, 67 (1): 125-132 http://dx.doi.org/10.1128/AEM.67.1.125-132.2001

Rabelo C. H. S., Härter C. J., Basso F. C., Lara E. C., Mari L. J., Chevaux E., Reis R.A. 2015. A meta-analysis of the effects of Lactobacillus buchnery associated or not with L. plantarum on the fermentation and aerobic stability of whole crop corn silages in tropical weather. $17^{\text {th }}$ International Silage Conference. Piracicaba, Sao Paulo, Brazil, p. 340

Reich L. J., Kung Jr. L. 2010. Effects of combining Lactobacillus buchneri 40788 with various lactic acid bacteria on the fermentation and aerobic stability of corn silage. Animal Feed Science and Technology, 159 (3-4): 105-109 http://dx.doi.org/10.1016/j.anifeedsci.2010.06.002

SAS. 2002. Statistical Analysis System. User's Guide: Statistics, version 8.02. SAS Institute Inc., Cary, USA

Schmidt R. J., Emara M. G., Kung Jr. L. 2008. The use of a quantitative real-time polymerase chain reaction assay for identification and enumeration of Lactobacillus buchnery in silage. Journal of Applied Microbiologv. 105 (3): 920-929 http://dx.doi.org/10.1111/j.1365-2672.2008.03834.x
Schmidt R. J., Kung Jr. L. 2010. The effects of Lactobacillus buchnery with or without a homolactic bacterium on the fermentation and aerobic stability of corn silages made at different locations. Journal of Dairy Science. 93 (4): 1616-1624 http://dx.doi.org/10.3168/jds.2009-2555

Ström K., Sjögren J., Broberg A., Schnürer J. 2002. Lactobacillus plantrum MiLAB 393 produces the antifungal cyclis dipeptides cyclo (L-Phe-L-Pro) and cyclo (L-Phe-trans4-OH-L-Pro) and 3-phenyllactic acid. Applied and Environmental Microbiology, 68 (9): 4322-4327 http://dx.doi.org/10.1128/AEM.68.9.4322-4327.2002

Tabacco E., Piano S., Cavallarin L., Bernardes T. F., Borreani G. 2009. Clostridia spore formation during aerobic deterioration of maize and sorghum silages as influenced by Lactobacillus buchneri and Lactobacillus plantarum inoculants. Journal of Applied Microbiologv. 107 (5): 1632-1641 http://dx.doi.org/10.1111/j.1365-2672.2009.04344.x

Tabacco E., Piano S., Revllo-Chion A., Borreani G. 2011. Effect of Lactobacillus buchnery LN4637 and Lactobacillus buchnery LN40177 on the aerobic stability, fermentation products, and microbial populations of corn silage under farm conditions. Journal of Dairy Science, 94 (11): 5589-5598 $\mathrm{http}: / / \mathrm{dx}$.doi.org/10.3168/jds.2011-4286

Weinberg Z. G., Chen Y., Azriely A., Szakacs G., Filya I. 2009. The quality of commercial wheat silages in Izrael. Journal of Dairv Science. 92 (2): 638-644 http://dx.doi.org/10.3168/jds.2008-1120

ISSN 1392-3196 / e-ISSN 2335-8947

Zemdirbyste-Agriculture, vol. 103, No. 3 (2016), p. 305-310

DOI $10.13080 /$ z-a.2016.103.039

\title{
Inokulianto įtaka kukurūzų siloso, pagaminto plastiko rankovèje, fermentacijai, mikrobų populiacijai ir aerobiniam stabilumui
}

\author{
J. Jatkauskas, V. Vrotniakienè \\ Lietuvos sveikatos mokslų universiteto Gyvulininkystės institutas
}

\begin{abstract}
Santrauka
Tyrimo metu buvo nustatyta inokulianto, sudaryto iš Lactobacillus buchneri ir homofermentatyvinių pieno rūgšties bakterijų, itaka kukurūzų siloso, pagaminto plastiko rankovèje, kokybei. Kukurūzų augalai, turintys $34 \%$ sausujų medžiagu (SM), buvo nupjauti, susmulkinti ir silosuoti didelèse (1700-1800 kg) plastiko rankovèse, pridedant vandens (kontrolinis silosas) arba inokulianto suspensijos (inokuliuotas silosas), kurioje buvo $1 \times 10^{8}$ kolonijas sudarančių vienetu (KSV) $\mathrm{ml}^{-1}$ Lactobacillus plantarum, Enterococcus faecium ir L. buchneri (20:30:50). Galutinè inokulianto ịterpimo norma buvo $1,0 \times 10^{5} \mathrm{KSV} \mathrm{g}^{-1}$ silosuojamos masės. Silosas lauko sąlygomis laikytas 156 dienas. Po to siloso rankovès buvo atidengtos ir paimti mėginiai siloso cheminei sudèčiai, mielių bei pelèsių kiekiui ir aerobiniam stabilumui nustatyti. Matomų pelèsių ant siloso paviršiaus augimas buvo nustatytas praejus $0,8,14$, 21,28 ir 35 dienų po hermetinès dangos nuo siloso rankovių nuèmimo ir vertintas pagal skalę nuo 0 iki 5 .

Tyrimo duomenimis, acto rūgšties koncentracija buvo esmingai didesnè inokuliutame silose, palyginus su kontroliniu $\left(20,3\right.$ vs $\left.17,1 \mathrm{~g} \mathrm{~kg}^{-1} \mathrm{SM}\right)$. Silosas su inokulianto priedu turẻjo mažesnius $\mathrm{pH}$ vertę, sviesto rūgšties koncentraciją ir pieno bei acto rūgščiu santyki nei kontrolinis $(1,95$ vs 1,80). Inokulianto priedas esmingai sumažino sausujų medžiagų nuostolius (87 vs $74 \mathrm{~g} \mathrm{~kg}^{-1} \mathrm{SM}$ ). Mielių ir pelèsių kiekis buvo esmingai mažesnis inokuliuotame silose, lyginant su kontroliniu; tai patvirtina inokulianto gebą pagerinti kukurūzų siloso aerobinị stabilumą. Matomais pelèsiais padengtas kontrolinio siloso paviršiaus plotas buvo buvo 4-5 kartus didesnis nei siloso, pagaminto su inokulianto priedu. Inokuliuoto siloso gedimas laboratorinėmis sąlygomis prasidejo 72 valandomis (3 dienomis) vèliau, lyginant su kontroliniu. Inokulantas gerokai padidino kukurūzų siloso aerobinį stabilumą jị laikant plastiko rankovèse lauko sąlygomis.
\end{abstract}

Reikšminiai žodžiai: aerobinis stabilumas, inokuliantas, kukurūzai, pelèsiai, silosas.

Please use the following format when citing the article:

Jatkauskas J., Vrotniakiene V. Effect of the inoculant on the fermentation, microbial populations and aerobic stability of whole plant maize ensiled in large tubes. Zemdirbyste-Agriculture, 103 (3): 305-310 DOI 10.13080/za.2016.103.039 